\title{
An Examination of the Courses for the Education of Exceptionally Talented Children in Special Education Teaching Programs in European Union Member States and Turkey
}

\author{
Nilay Kayhan ${ }^{1} \&$ Pelin Pistav Akmese ${ }^{2}$ \\ ${ }^{1}$ Department of Special Education, Hasan Kalyoncu University, Gaziantep, Turkey \\ ${ }^{2}$ Department of Special Education, Ege University, Izmir, Turkey \\ Correspondence: Nilay Kayhan, Department of Special Education, Hasan Kalyoncu University, Gaziantep, \\ Turkey.
}

Received: September 14, 2018

doi:10.5539/jel.v7n6p230

\begin{abstract}
Legal regulations about education and educational policies are important for the quality of the practices. It has been seen that many countries invest in the education of the individuals who will form a qualified society in the future and focus on the teacher training and quality. The teachers have a great role in determining the exceptionally talented individuals in Turkey, their education, directing their performances in accordance with their interests and talents, enabling them to benefit from support education. Accordingly, in order to determine what kind of competency the teachers gain regarding this pre-service area, the courses in the special education teaching undergraduate programs regarding the exceptionally talented area in European Union (EU) and Turkey have been investigated in terms of number, term and credit content. Qualitative research method and document analysis technique are used in the descriptive study which aims to determine an existing situation. The data were obtained from education reports published by EU member countries about their own education systems, United Nations Children Rights and Education reports and Council of Higher Education's Teacher Training Programs. For example, the preservice teachers are given theoretical information in the first classes, then receive education in which they can observe and show effective teaching skills with a mentor in the following years in the countries such as Belgium, the Czech Republic, Finland, Spain, Sweden, Luxemburg, and Malta.
\end{abstract}

Keywords: special education, teaching programs, talented individuals, European Union (EU)

\section{Introduction}

\subsection{Introduce the Problem}

1) Why is this problem important?

It is inevitable to update both compulsory education curriculum and teacher training programs in order to acquire technological changes, to determine and guide the students in accordance with their interests and skills in the earliest period. Because, school life is a process in which the students learn, prepare for life, find themselves and also their skills are observed by their families and teachers. This study, which is conducted with the idea that the special education teachers who are a part of the personnel in the education of the children with individual differences in the education levels including preschool, primary school, secondary school and high school periods have an important role in discovering the exceptional talents and supporting students in academic, social and emotional sense aims to examine the courses related to exceptionally talented area in terms of number, content and credit.

2) How does the study relate to previous work in the area? If other aspects of this study have been reported previously, how does this report differ from, and build on, the earlier report?

Special education teacher training program was started as of 1983-84 in the faculty of education of the universities with educational sciences department. The preservice teachers who graduated as special education teachers from the program which was accepted as a single field until 1997-1998 participated in the education of visually impaired, hearing impaired, orthopedically disabled, mentally disabled and gifted children. Special Education Program was transformed into "Department" in 1997-1998 and started to train teachers in 5 different 
departments which are "Mentally, Visually, Hearing, Multi Disabled and Gifted fields". With the decision made by the Council of Higher Education, five departments were turned into Department of Special Education Special Education Teaching Program as of 2016-2017 academic year. Special Education Teaching Undergraduate program, one of the 25 teacher training undergraduate programs which were completed in May 2018 and will be applied as of 2018-2019 academic year in Turkey, has been seen as study which is related to the quality pursuit in teacher training in Turkey's educational policies. The teacher training working group in the body of Council of Higher Education gives importance to training qualified teachers in order to be able to use both subject field competency and professional knowledge and skills in practice, to train full equipped personnel in the pre-profession period (Council of Higher Education YOK, 2018).

Legal regulations about education and educational policies are important for the quality of the practices. It has been seen that many countries invest in the education of the individuals who will form a qualified society in the future and focus on the teacher training and quality. The teachers have a great role in determining the exceptionally talented individuals in Turkey, their education, directing their performances in accordance with their interests and talents, enabling them to benefit from support education. Accordingly, in order to determine what kind of competency the teachers gain regarding this pre-service area, the courses in the special education teaching undergraduate programs regarding the exceptionally talented area in European Union (EU) and Turkey have been investigated in terms of number, term and credit content qualitative research method and document analysis technique are used in the descriptive study which aims to determine an existing situation. The data were obtained from education reports published by EU member countries about their own education systems, United Nations Children Rights and Education reports and Council of Higher Education's Teacher Training Programs. It has been seen that while there are differences in the terms, credits and contents of the courses about the exceptionally talented in undergraduate programs, the most distinctive characteristic is the difference in the theoretical and applied parts of the courses. For example, the preservice teachers are given theoretical information in the first classes, then receive education in which they can observe and show effective teaching skills with a mentor in the following years in the countries such as Belgium, the Czech Republic, Finland, Spain, Sweden, Luxemburg, and Malta.

3) What are the primary and secondary hypotheses and objectives of the study, and what, if any, are the links to theory?

The teachers have a great role in determining the exceptionally talented individuals in Turkey, their education, directing their performances in accordance with their interests and talents, enabling them to benefit from support education. Accordingly, in order to determine what kind of competency the teachers gain regarding this pre-service area, the courses in the special education teaching undergraduate programs regarding the exceptionally talented area in European Union (EU) and Turkey have been investigated in terms of number, term and credit content.

This study, which is conducted with the idea that the special education teachers who are a part of the personnel in the education of the children with individual differences in the education levels including preschool, primary school, secondary school and high school periods have an important role in discovering the exceptional talents and supporting students in academic, social and emotional sense aims to examine the courses related to exceptionally talented area in terms of number, content and credit.

4) How do the hypotheses and research design relate to one another?

Qualitative research method and document analysis technique are used in the descriptive study which aims to determine an existing situation. The data were obtained from education reports published by EU member countries about their own education systems, United Nations Children Rights and Education reports and Council of Higher Education's Teacher Training Programs. It has been seen that while there are differences in the terms, credits and contents of the courses about the exceptionally talented in undergraduate programs, the most distinctive characteristic is the difference in the theoretical and applied parts of the courses.

5) What are the theoretical and practical implications of the study?

The teachers should have implementing skills as well as subject field efficacies and should follow the innovations in science and math, so that the individuals can receive an education as questioning, productive, innovator individuals who can cooperate in accordance with entrepreneurship culture and cooperation and can follow technological and scientific developments in our education system (Ministry of National Education MEB, 2016; Council of Higher Education YOK; 2012a, YOK, 2012b; YOK, 2018). In this sense, a comparison of teacher training programs in an international sense is significant and the teachers should take the individual differences into account and aim to train students as individuals who have high level thinking skills, can develop 
products, have teamwork skills, are not afraid of making mistakes and have high level of self-confidence instead of giving the theoretical information with direct speech.

As a result, the findings of this comparative study have been thought to contribute to the assessment of special education teaching program, Bologna process studies in teacher training programs and regulations related to the ECTS compatibility of the courses. On the other hand, providing the knowledge and skills required by the century to the teachers who will work with exceptionally talented individuals also serves for forming a qualified society intention of the countries.

\subsection{Explore Importance of the Problem}

Developments in information and communication technologies affect the human life and direct the education policies of the countries. It draws attention that today many countries give importance to early education and equal access, participation, implementing necessity-oriented education programs in their education policies. Because a society's being a more qualified and healthy structure is closely related to the individual's receiving an education which helps to improve their personal efficacies. Thus, there are studies to qualify education institutions in terms of quality and quantity, to enable all children to receive education regarding their necessities in terms of cognitive, social, language and affective characteristics in early period in Turkey as well as all over the world (Council of European-CCEA, 2006; Davasligil, 2004; European Commission-EC, 2006; 2011, 2018; Ministry of National Education MEB, 2012a, 2012b, 2018; Sak, 2018).

Educational regulations are highly important for the individuals who show different developmental characteristics and accordingly higher performances than their peers in creativity, intelligence, art, sports, leadership and other academic areas (such as mathematics, science, language skills). Particularly parents and teachers should know the developmental characteristics of the children who show different and advanced development from their peers and should have knowledge about what kind of interventions can be used regarding this (EC, 2011, 2018; Ministry of National Education MEB, 2012a, 2012b, 2018; Pretis, 2009; UNICEF, 2011). In the last regulations made by the Ministry of National Education in Turkey, exceptional talent term is preferred instead of "giftedness/genius" terms.

While it is highly important to determine exceptionally talented children in early periods, these characteristics generally include different areas since the babyhood such as oversensitivity, attention ability, multi-directional quick thinking, advanced level of research, boldness, a wide range of imagination and fantasy, seeing the details and ability to argue, consistent hardworking excessive sense of wonder, a strong memory and quick learning ability, sensitivity, quick language development in early period compared to their peers (Baykoç-Dönmez, 2010). However, it has been stated that the families feel anxious about determining in the early period and support in education processes, are in search of the person or people or institution to get support. Just as in the other developmental differences, accurate guidance and support services which will be provided to the exceptionally talented children and their families in this period are highly important (CCEA, 2006; Ministry of National Education MEB, 2012a, 2012b, MEB, 2018; Miedel \& Reynolds, 1999; Mönks \& Pflüger, 2005; Pretis, 2009). The quality of the education institutions and professional knowledge of the teachers are important in supporting the child and the family before and after the compulsory education practices start, and the teachers' efficacy to work with these individuals and subject field proficiency are closely related to the education they received before the profession (Baykoç-Dönmez, 2010; CCEA, 2006; EC, 2006; 2011; 2018a, 2018b, 2018c; Emir, 2017; EU, 2017a, 2017b; Ministry of National Education MEB, 2012a, 2012b).

The quality of an institution is related to the knowledge, skills and professional efficacies of the personnel who work in that institution. Today, instead of being shut in for walls and limited livings, the necessity for the life-long learning processes which are based on the individuality of the individual in accordance with his/her performance and abilities has been argued (EACEA, 2018; EC, 2011; EC, 2018b; Eurydice, 2011; EU, 2017a; UNICEF, 2011). In this regard, it is necessary to create effective educational environments for the students who show different developmental characteristics from their peers and whose exceptional talents are determined, to make regulations in curriculum to make the child and family based researches widespread (Davasligil, 2004; Enç, 2003; Ministry of National Education MEB, 2018, Council of Higher Education YOK, 2018). The main responsibility belongs to the teachers in creating and implementing effective teaching. Thus, it is highly significant to evaluate the education, professional efficacies and teaching skills of the teachers who work in special education field in which the individual needs and existing performance level are taken into account more intensely (EC, 2011, 2018; Idin and Kayhan, 2016; Pretis, 2009, Council of Higher Education YOK, 2018).

European Union (EU) consists of the accession of 28 member countries. When the accession years of these countries are investigated, it is created with the association of Belgium, France, Germany, Italy, Luxemburg and 
Holland (6 countries), and Denmark, inclusion of Ireland and United Kingdom in 1973, Greece in 1981, Portugal and Spain in 1986, Austria, Finland and Sweden in 1995, Cyprus, the Czech Republic, Estonia, Hungary, Latvia, Lithuania, Malta, Poland, Slovakia, Slovenia in 2004, Bulgaria and Romania in 2007, lastly Croatia in 2013 joined the EU (EU, 2017). When investigating the purposes of these countries which have cooperation in various areas such as economy, culture and education, health, energy, environment, human rights and citizenship, customs, tax, foreign affairs, employment, technology, science, social justice, sports, civil defense, multiculturalism, it has been seen that each country is responsible for its own education policies, however they have the responsibility of determining mutual aims and sharing effective practices. When investigating the educational aims of these 28 countries, it has been seen that they give priority to early education, language and culture based differences, total access and participation of the individuals with special needs and with social and cultural disadvantages to the education, they care about the support that will be provided to the individual and the family and make an effort to adopt lifelong learning philosophy. On the other hand, each country forms national educational goals in their curriculum and use accountability principle and international recognisability criteria as a base in the national sense in terms of learning outcomes. In this regard, educational designs based on the progressive and technological developments, qualities in teacher training, comparative studies and opportunities, student and teacher mobility are among the primary educational goals of European Union member countries. Many countries which start education at early ages and provide early access to preschool, also adopt employment and integration based practices as a social policy in order to support independent life skills and transition skills, in this sense to enable professional education and employment areas, to provide support in higher education period by non-governmental organizations, employers and service industry workers in industry field (EC, 2006, 2011, 2018a, 2018b, 2018c, EU, 2017a, 2017b).

\subsection{State Hypotheses and Their Correspondence to Research Design}

The data of the study were investigated with document analysis technique and the course content in special education teaching undergraduate programs of the universities were examined with the key words such as "exceptionally talented, genius, gifted, early childhood, primary school, secondary school, high school education levels, individual with special needs, discovering talents in preschool period, based on individual differences". Information on the websites of European Union (EU), Eurydice and Council of Higher Education (YOK) was used as a base.

\section{Method}

In this descriptive study, courses about the exceptionally talented field in the special education teaching undergraduate programs in Turkey and European Union (EU) member countries were examined in terms of credit, number and content. The data of the study were investigated with document analysis technique and the course content in special education teaching undergraduate programs of the universities were examined with the key words such as "exceptionally talented, genius, gifted, early childhood, primary school, secondary school, high school education levels, individual with special needs, discovering talents in preschool period, based on individual differences". Information on the websites of European Union (EU), Eurydice and Council of Higher Education (YOK) was used as a base. It has been stated that the programs which train teachers for the special education field are similar in terms of the courses, but they differ in the number and contents of the courses. Faculties of education of some EU member countries and the Special Education Teaching programs constituted by the Council of Higher Education (YOK) and put into effect in 2016 were examined, then it is organized in accordance with the special education teaching undergraduate program which will be applied as of 2018-2019 academic year with the regulations made in 2018. The data regarding independent variables of our study were obtained from Agencies of the European Union, Eurydice-Network on Education Systems and Policies in Europe publications. The data were gained by investigation of the syllabi in the special education teaching undergraduate programs of the Council of Higher Education stated in the National Education System Descriptions reports of each country.

\section{Results}

\subsection{The System of Special Education Teacher Education in Turkey}

Special education teacher training program was started as of 1983-84 in the faculty of education of the universities with educational sciences department. The preservice teachers who graduated as special education teachers from the program which was accepted as a single field until 1997-1998 participated in the education of visually impaired, hearing impaired, orthopedically disabled, mentally disabled and gifted children. Special Education Program was transformed into "Department" in 1997-1998 and started to train teachers in 5 different departments which are "Mentally, Visually, Hearing, Multi Disabled and Gifted Fields". With the decision made 
by the Council of Higher Education, five departments were turned into Department of Special Education Special Education Teaching Program as of 2016-2017 academic year. Special Education Teaching Undergraduate program, one of the 25 teacher training undergraduate programs which were completed in May 2018 and will be applied as of 2018-2019 academic year in Turkey, has been seen as study which is related to the quality pursuit in teacher training in Turkey's educational policies. The teacher training working group in the body of Council of Higher Education gives importance to training qualified teachers in order to be able to use both subject field competency and professional knowledge and skills in practice, to train full equipped personnel in the pre-profession period (Council of Higher Education YOK, 2018). For this purpose, a cooperation is formed with the related units of Ministry of National Education and applied workshops in which the opinions of the academicians who work in universities and of the experts who work in the field are taken. There are two ways of determining/diagnosing the exceptionally talented individuals in Turkey. These are conducted by diagnosing in Science and Art Center (BILSEM) process or application to Counseling and Research Center (RAM). Diagnosis consists of referring, group scan and individual application processes. BILSEM is an institution in which the individuals are educated at each educational level starting from preschool, take supportive education in arts, general mental skills and music in addition to the educational process in general education institutions. These independent education institutions aim to enable exceptional students to realize their individual skills and reach the higher levels of their performances (Ministry of National Education MEB, 2018).

The new undergraduate program which will be applied in the 2018-2019 academic year in Turkey includes a direct course named "learning disability and exceptional talent" besides the general courses regarding the special education area. It has drawn attention that it is handled together with other special need areas in integration, assessment, observation and institutional experience courses (Council of Higher Education YÖK, 2018). In this study which was conducted with the idea that the courses taken by the teachers in preservice period, their content and way of application can directly affect teachers' professional efficacy and effective teaching skills, the number, credit and content of the courses related to exceptional talent field in the special education teaching undergraduate programs in some EU countries and Turkey were compared. The findings are shown in Table 1, Table 2 and Table 3 . The distribution of the courses by years in terms of number is shown in Table 1.

Table 1. The distribution of the courses regarding the exceptionally talented field in the special education teaching programs in EU member countries and Turkey by years

\begin{tabular}{llllll}
\hline Countries & $1^{\text {st }}$ year & $2^{\text {nd }}$ year & $3^{\text {rd }}$ year & $4^{\text {th }}$ year & Total \\
\hline Austria & 1 & 2 & - & 1 & 4 \\
Belgium & 1 & 2 & - & 1 & 4 \\
the Czech Republic & 2 & - & - & - & 2 \\
Denmark & - & 2 & 1 & 1 & 4 \\
Finland & 3 & 1 & 1 & 1 & 6 \\
Netherlands & 2 & 2 & - & - & 4 \\
Ireland & 2 & 2 & - & 1 & 5 \\
Spain & 2 & 2 & 1 & 1 & 6 \\
Sweden & 2 & 2 & 1 & 1 & 6 \\
Cyprus & 2 & 2 & - & - & 4 \\
Lithuania & 2 & 1 & 1 & - & 4 \\
Luxemburg & 2 & 1 & 1 & 1 & 5 \\
Hungary & 1 & 1 & - & 1 & 3 \\
Malta & 1 & 2 & 2 & 1 & 6 \\
Poland & 1 & 2 & - & - & 3 \\
Portugal & 1 & 2 & 1 & - & 4 \\
Slovenia & 2 & 2 & 1 & 1 & 6 \\
Turkey & 1 & 2 & 1 & - & 4 \\
Greece & 1 & - & - & 1 & 2 \\
\hline
\end{tabular}

As seen in Table 1, education of the exceptionally talented individuals and the year and number of the courses given to the teachers who study in special education departments differ in EU member countries and Turkey. In Turkey, legal regulations as well as the education of exceptionally talented individuals, determining in learning environment and guidance, behavioral characteristic are given in the Learning Disability and Exceptional Talent (4 ECTS) course in the second academic term, in integration in Special Education (2 ECTS) in the third term, in Observation in Special Education Institutions (5 ECTS) (subject field course) in the fourth term and in School 
and Institution Experience in Special Education in the sixth term. When the practices in the programs in EU countries are investigated, it has been seen that the 240 ECTS program shows a 3-stage program structure (General educational science, field-specific education and professional practices regarding special education field) in most countries (Austria, Spain, Cyprus, Portugal, Poland, Hungary, and Greece).

In some countries such as Finland and Denmark, both the practical internship and the structure of the program are highly remarkable. The program structure in Denmark has 4 stages and these stages are Main Teacher Efficacies, Subject Field Teaching, Teaching Practice and Dissertation in the Field. The preservice teachers gain practical experience in internship periods in the $1^{\text {st }}, 2^{\text {nd }}$ and $4^{\text {th }}$ years of the 4-year program. In this sense, in the distribution of the courses regarding the special education and exceptionally talented individuals, (Finland, Spain, Sweden, Malta and Slovenia) are the countries in which the preservice teachers take the highest number of the courses with 6 courses in total. The teachers who will work in special education field graduate taking 5 courses in Ireland, 4 courses in Austria, Belgium, Denmark, Holland, Southern Cyprus, Lithuania and Portugal; 3 courses in Hungary and Poland and 2 courses in the Czech Republic. It has drawn attention that the courses related to this field are included in the whole education process in Finland, Spain, Sweden, Luxemburg, Malta and Slovenia among EU member countries.

Table 2. The ECTS distribution of the courses regarding the exceptionally talented field in the special education teaching programs in EU member countries and Turkey by years

\begin{tabular}{llllll}
\hline Countries & $1^{\text {st }}$ year & $2^{\text {nd }}$ year & $3^{\text {rd }}$ year & $4^{\text {th }}$ year & ECTS Credit(Total) \\
\hline Austria & 10 & 15 & - & 15 & 40 \\
Belgium & 5 & 10 & - & 8 & 23 \\
the Czech Republic & 18 & - & - & - & 18 \\
Denmark & - & 20 & 10 & 10 & 40 \\
Finland & 17 & 6 & 6 & 6 & 35 \\
Netherlands & 15 & 15 & - & - & 30 \\
Ireland & 15 & 15 & - & 5 & 35 \\
Spain & 12 & 12 & 6 & 6 & 36 \\
Sweden & 15 & 15 & 7.5 & 7.5 & 45 \\
Cyprus & 20 & 18 & - & - & 38 \\
Lithuania & 10 & 5 & 5 & - & 20 \\
Luxemburg & 6 & 3 & 3 & 8 & 20 \\
Hungary & 6 & 6 & - & 6 & 18 \\
Malta & 4 & 8 & 8 & 4 & 24 \\
Poland & 10 & 15 & - & - & 25 \\
Portugal & 4 & 10 & 6 & - & 20 \\
Slovenia & 7 & 9 & 7 & 5 & 28 \\
Turkey & 4 & 7 & - & - & 16 \\
Greece & 4 & - & & 4 & 8 \\
\hline
\end{tabular}

As seen in Table 2, the total ECTS of the courses taken by the preservice teachers in the undergraduate programs which train teachers for special education field in EU member countries and Turkey shows similarity. While Sweden has the highest ECTS with 45 ECTS, Austria, Denmark, Finland, Holland, Ireland, Spain, Cyprus follow it with 30 ECTS and above in the field- specific courses taken by the preservice teachers in special education field such as the education of exceptionally talented individuals, diagnosis and assessment process, preparing individualized education programs in education environments and appropriate regulations, transition to adulthood and professional life programs, support processes for the exceptional children, their family and teachers, type of the education programs regarding the families. While the total ECTS of the courses related to exceptional talent field in Greece is 8, Turkey has 16 ECTS of courses, which are Learning Disability and Exceptional Talent (4 ECTS - compulsory course), Integration in Special Education (2 ECTS - compulsory course), observation in special education institutions (5 ECTS - subject field course) and School and Institution Experience in Special education (5 ECTS). While the exceptionally talented individual term is used directly in Learning Disability and Exceptional Talent course, information about the regulations regarding all individuals with special needs in integration concept was given and a term regarding the exceptional talent was not used. In the institution observation course within field education, the preservice teacher has the opportunity to observe exceptional children in Science and Art Centers in which they receive supportive education in out-of-school time in the scope of a program which accepts individuals with an exam in the exceptional talent field in Turkey. 
Table 3. Contents of the courses regarding the exceptionally talented field in the special education teaching programs in EU member countries and Turkey

\begin{tabular}{|c|c|c|c|c|}
\hline \multicolumn{5}{|c|}{ Course content } \\
\hline Countries & $1^{\text {st }}$ year & $2^{\text {nd }}$ year & $3^{\text {rd }}$ year & $4^{\text {th }}$ year \\
\hline Austria & $\begin{array}{l}\text { Place of the exceptionally talented in } \\
\text { special education field. Education } \\
\text { policies regarding exceptionally } \\
\text { talented individuals }\end{array}$ & $\begin{array}{l}\text { Assessment and educational needs } \\
\text { of the Exceptionally Talented } \\
\text { Children (ETC) } \\
\text { Counseling to family and } \\
\text { individuals in school environment }\end{array}$ & - & $\begin{array}{l}\text { Practice } \\
\text { Enriched }\end{array}$ \\
\hline Belgium & $\begin{array}{l}\text { How do exceptionally talented } \\
\text { children learn in early childhood and } \\
\text { primary school? }\end{array}$ & $\begin{array}{l}\text { ETC Assessment and } \\
\text { Multiculturalism Educational needs } \\
\text { educational adaptations }\end{array}$ & - & $\begin{array}{l}\text { ETC placement } \\
\text { processes } \\
\text { Observation } \\
\end{array}$ \\
\hline $\begin{array}{l}\text { The Czech } \\
\text { Republic }\end{array}$ & $\begin{array}{l}\text { ETC Assessment and Appropriate } \\
\text { Educational Environments } \\
\text { Efficacy of teachers working with } \\
\text { ETC Science and Art education }\end{array}$ & - & - & - \\
\hline Denmark & - & $\begin{array}{l}\text { Teaching planning for ETC ETC } \\
\text { teaching strategies ETC integration } \\
\text { philosophy }\end{array}$ & $\begin{array}{l}\text { Professionalefficacie } \\
\mathrm{s} \text { to work with ETC }\end{array}$ & $\begin{array}{l}\text { Institution } \\
\text { observation } \\
\text { dissertation }\end{array}$ \\
\hline Finland & $\begin{array}{l}\text { ETC in special education. field. } \\
\text { Adaptation of ETC to teaching } \\
\text { environments. Information technologies } \\
\text { in education for ETC }\end{array}$ & ETC assessment and teaching plan & $\begin{array}{l}\text { Counseling for life } \\
\text { long education }\end{array}$ & Subject- project \\
\hline Netherlands & $\begin{array}{l}\text { ETC individual differences } \\
\text { Communication skills adaptive } \\
\text { behavioral support process for ETC }\end{array}$ & $\begin{array}{l}\text { Interaction with ETC in learning } \\
\text { environments Interaction with } \\
\text { families and counseling } \\
\end{array}$ & - & - \\
\hline Ireland & $\begin{array}{l}\text { Assessment of characteristics of ETC } \\
\text { Preparing syllabus for ETC }\end{array}$ & $\begin{array}{l}\text { Supporting out-of-school learning } \\
\text { for ETC ETC communication and } \\
\text { family counseling }\end{array}$ & - & $\begin{array}{l}\text { Subject-specific } \\
\text { observation, } \\
\text { presentation }\end{array}$ \\
\hline Spain & $\begin{array}{l}\text { ETC individual differences } \\
\text { ETC family and school relationships }\end{array}$ & $\begin{array}{l}\text { ETC reasoning, robotics education } \\
\text { plastic arts and music education } \\
\text { ETC peer interaction education }\end{array}$ & $\begin{array}{l}\text { ETC creating } \\
\text { innovative learning }\end{array}$ & $\begin{array}{l}\text { ETC, policies, educ. } \\
\text { practice }\end{array}$ \\
\hline Sweden & $\begin{array}{l}\text { Giftedness in terms of child rights, } \\
\text { Assessment for ETC }\end{array}$ & $\begin{array}{l}\text { Adaptation and planning of } \\
\text { teaching for ETC, ETC family, } \\
\text { school and society interaction }\end{array}$ & $\begin{array}{l}\text { Co-teaching } \\
\text { practices for ETC in } \\
\text { early childhood }\end{array}$ & $\begin{array}{l}\text { Subject-observation } \\
\text { at schools and } \\
\text { project management }\end{array}$ \\
\hline Cyprus & $\begin{array}{l}\text { ETC assessment and guidance to } \\
\text { education environments }\end{array}$ & $\begin{array}{l}\text { Educational practices for ETC } \\
\text { ETC development of curricula }\end{array}$ & 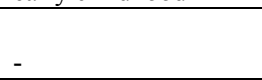 & 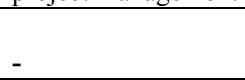 \\
\hline Lithuania & $\begin{array}{l}\text { ETC characteristics education. } \\
\text { Education based on individual } \\
\text { differences }\end{array}$ & $\begin{array}{l}\text { ETC use of digital games in } \\
\text { education }\end{array}$ & $\begin{array}{l}\text { Art ed. and drama in } \\
\text { ETC classes }\end{array}$ & - \\
\hline Luxemburg & $\begin{array}{l}\text { Education based on individual } \\
\text { differences. Observation in ETC } \\
\text { schools }\end{array}$ & $\begin{array}{l}\text { Innovations in science and math } \\
\text { education for ETC }\end{array}$ & $\begin{array}{l}\text { Transition to digital } \\
\text { age in special edc. }\end{array}$ & Practices for ETC \\
\hline Hungary & Assessmentand guidance for ETC & $\begin{array}{l}\text { Project management with } \\
\text { non-governmentalorganizations for } \\
\text { ETC }\end{array}$ & - & $\begin{array}{l}\text { ETC inst. } \\
\text { observation }\end{array}$ \\
\hline Malta & $\begin{array}{l}\text { Organizing teaching environments for } \\
\text { special needs Innovative } \\
\text { learningenvironments }\end{array}$ & $\begin{array}{l}\text { Adapted contents for ETC Digital } \\
\text { learning contents in the } 21^{\text {st }} \text { century }\end{array}$ & $\begin{array}{l}\text { Supporting scientific } \\
\text { process skills of ETC. } \\
\text { Art creative and } \\
\text { effective thinking }\end{array}$ & $\begin{array}{l}\text { Teach. design and } \\
\text { technology support } \\
\text { for ETC }\end{array}$ \\
\hline Poland & ETC assessment and placement & $\begin{array}{l}\text { Individualized education practices } \\
\text { for ETC. ETC curriculum designs }\end{array}$ & - & - \\
\hline Portugal & Individualized education & $\begin{array}{l}\text { Special education for ETC. } \\
\text { Education technologies and use of } \\
\text { digital media for ETC }\end{array}$ & $\begin{array}{l}\text { Special ed. legal } \\
\text { legislations for ETC }\end{array}$ & - \\
\hline Slovenia & $\begin{array}{l}\text { Classifying in special education } \\
\text { ETC education }\end{array}$ & $\begin{array}{l}\text { Special education policies } \\
\text { ETC teaching environments }\end{array}$ & $\begin{array}{l}\text { Preparing IEP for } \\
\text { ETC }\end{array}$ & $\begin{array}{l}\text { Transition prog for } \\
\text { ETC (adulthood and } \\
\text { professional life) }\end{array}$ \\
\hline Turkey & $\begin{array}{l}\text { ETC attitude toward individual and } \\
\text { families services, support and legal } \\
\text { right for families }\end{array}$ & $\begin{array}{l}\text { Integration in special education } \\
\text { Observation in special education } \\
\text { schools and institutions }\end{array}$ & $\begin{array}{l}\text { Specialed.institution } \\
\text { teaching practices } \\
\text { school experience }\end{array}$ & - \\
\hline Greece & Special education and ETC & - & - & $\begin{array}{l}\text { Teaching prac. in } \\
\text { special ed.. Learning } \\
\text { and program }\end{array}$ \\
\hline
\end{tabular}


As shown in Table 3, it draws attention that the courses regarding the determination of exceptionally talented students at early ages, enabling them to benefit from the support programs after appropriate diagnosis and assessment and how the practices regarding preparation of curriculum are included in the first two years of undergraduate programs in EU member countries and Turkey. While need based courses under classifying exceptionally talented children in special education field are given in the first year in the countries such as Austria, Finland, Ireland, Spain, Cyprus, Lithuania, Slovenia and Greece, the course contents about determining exceptionally talented children at early ages, education policies and what kind of developmental characteristics the children show starting from early ages draw attention in Belgium. In the Czech Republic, Finland, Luxemburg, the fact that the preservice teachers who will work with exceptionally talented children experience professional efficacy, creating appropriate education environments, information and communication technologies for exceptionally talented students, taking education based on the scientific process skills of the preservice teachers and institution observation in the first two academic terms can be thought as a remarkable finding. While preservice teachers learn theoretical information about attitude towards exceptional children and their family, services provided, support and legal rights provided for the families in 4-ECTS Learning Disability and Exceptional Talent course which is given in the second term of the first year in Turkey, similarly Sweden gives information about Exceptionally talented individuals to the preservice teachers in the course content of Exceptional Talent in terms of Child Rights and assessment processes for ETC.

When examining the course contents in the third and fourth academic terms of the second year; it is seen that the courses based on the education policies and educational regulations regarding the integration of the exceptional children like all the individuals with special needs in the general education settings and in the society they live in are included with a conception generally based on integration. While Belgium, Denmark, Finland and Sweden have a course content based on the regulations which are based on the needs of the multicultural education settings and needs of the individuals who learn differently, similarly preservice teachers in Turkey take courses about legal rights and integration and make observations in the special education schools and institutions in the second year.

Remarkable subjects in the course contents of Netherlands, Ireland, Spain and Sweden are supporting the family and peer interaction, social adaptation periods, while the preservice teachers in Hungary are responsible for determining a category in the special education field in which the exceptional children will be included and for preparing a project with a non-governmental organization. Artificial intelligence applications whose effectiveness has been argued recently and which are very beneficial when used properly, learning process with robots, activities based on mind games and teaching environments enriched with digital content are included in the special education undergraduate programs of Spain, Lithuania, Luxemburg, Malta and Portugal. In the literature, it has drawn attention that STEM (Science, Technology, Engineering and Mathematic-STEM) studies have an importance in general education environments, coding courses are included in teacher training programs, studies are conducted to provide more qualified support services to the child and the family in terms of counseling and education materials (İdin \& Kayhan, 2016; Ministry of National Education MEB, 2016; Council of Higher Education YOK, 2018).

Another striking finding of the study is that third year of the undergraduate programs generally focuses on preparing individualized education plans and observing the development of the individual, assessment, guidance and preparing a family counseling based plan. Countries' education policies and legal regulations about the professional efficacy of the teachers who will work with ETC and supportive education which will be provided to the teacher, how to provide them are given theoretically. It has drawn attention that many countries have institution observation and professional practice in the $6^{\text {th }}, 7^{\text {th }}$ and $8^{\text {th }}$ terms similar to Turkey. While preservice teachers undergo institution observation, preparing syllabus, project management and finalization, assessment of their own learning outcomes with presentation processes in Austria, Denmark, Finland, Ireland, Sweden and Luxemburg, preservice teachers in Turkey prepare an internship file after the school experience and are assessed by the academic member of the related faculty. It can be accepted as a remarkable detail that preservice teachers take theoretical and applied courses about the grade passing of exceptional children, their needs in the transition to adulthood and professional life and efficacies for the teachers to give this support in the $4^{\text {th }}$ year in Malta, Slovenia and Greece.

\section{Discussion}

The societies which update their education policies in order to keep up with the science world which develops at a great pace accept that the quality is important in education. For example, preservice teachers take courses about creating learning environments, creative drama, innovative learning, digital developments and brain relationship, information technologies and coding, art and sports activities, out-of-school learning environments and robotics 
in order to gain efficacy to work with exceptionally talented individuals in Belgium, the Czech Republic, Finland, Spain, Sweden, Lithuania, Luxemburg and Malta (EC, 2018a; EC, 2018b; EU, 2017a; EU, 2017b; Idin \& Kayhan, 2016; Miedel \& Reynolds, 1999; Mönks \& Pflüger, 2005; TUBITAK (The Scientific and Technological Research Council of Turkey-TUBITAK, 2012; UNICEF, 2011).

Curriculum based on the individual differences provide a compulsory education opportunity for the children with special needs, in which they fully participate with their peers (Davasligil, 2004; EC, 2018a; EC, 2018b; EU, 2017a; EU, 2017b; Idin \& Kayhan, 2016; Miedel \& Reynolds, 1999; Mönks \& Pflüger, 2005; Sak, 2018; TUBITAK, 2012; UNICEF, 2011). Of course, the most important people in this process are the families and teachers who directly participate in the educational activities of the children. The teachers should have quality pre-profession educations under expert supervision with applied practices and effective feedback should be provided to the teachers about their learning. In this sense, teachers' intelligence tests, use of these test and determining exceptional talents and training in accordance with their education are important. Turkey's first domestic intelligence test Anadolu SAK- Intelligence Scale (ASIS) (2018) was developed by Prof. Dr. Uğur SAK from Anadolu University and his team with university project support and Ministry of National Education application support. ASIS is a test, whose pilot stage was made with 1201 children between the ages of 4-12, standardization is made with 4641 children and validity, reliability study was made with 800 children including special education groups. Sak (2018) has stated that ASIS is the intelligence test with the highest representation power in terms of the age-based sample among the individual intelligence tests around the world and it has perfect reliability and validity levels. In this sense, the implementer education and formation training practices of ASIS (Anadolu-Sak Intelligence Scale) which is started to use in determining exceptionally talented individuals are conducted by ASIS instructors (ASIS, 2018; Kirişçi \& Sak, 2018; Sak, Bal Sezerel, Ayas, Tokmak, Ozdemir, N.; Demirel Gürbüz \& Opengin, 2016).

When investigating the special education teaching programs, there are some similarities and differences between some EU member states and Turkey in terms of admission criteria, courses, credit, term and graduation criteria. In Turkey, grade point average should be at least 2, 00 over 4,00 in the program which consists of 8 academic terms and in which the students should get minimum 240 ECTS credits. The preservice teachers who start studying in special education departments receive educational sciences, early childhood and special education field joint course in the countries such as Sweden, Finland, and Lithuania. The students who receive the pass grade with half theoretical and half applied practices enter a mid-term efficacy exam. On the other hand, teacher training in Denmark has been designed as 4 stages and based on efficacy with a more holistic viewpoint. The structure of the teacher training undergraduate program in Denmark includes "Main teacher efficacies, Subject Field Teaching, Teaching Practice and Dissertation in the Field". The preservice teachers gain practical experience in internship period in the $1^{\text {st }}, 2^{\text {nd }}$ and $4^{\text {th }}$ years of the 4 -year undergraduate program. Especially the special education teachers who will work with the children with special needs in their early childhood and primary school years and who will work in secondary schools receive a field-based education after the first 1.5 years of education. For example, the preservice teachers who are trained based on preschool basic education for early childhood, based on general education primary school level for primary education and are accepted to the programs as branch teachers for secondary school level. Thus, the teachers graduate with a career education as a result of performance and efficacy based education (CCEA, 2006; EC, 2018a, b; EU, 2017a).

The exceptionally talented children continue their education with their peers in many of the EU countries and Turkey. However, educational policies which include determining the exceptionally talented children in early childhood affected the teacher training systems in many of the EU countries (Finland, Greece, Malta, Spain, Sweden etc.). In Austria, Belgium, Portugal, Finland and Poland, the children who are gifted and have better ability characteristics compared to their peers can enroll in schools one year before the compulsory educational age. In this sense, the teachers gain career degrees such as preschool special education teacher and primary school special education teacher in accordance with the area of need. The courses they receive during the undergraduate program are planned in accordance with the age group. It is seen that the teachers receive courses related to early childhood and preschool period, attend academic projects about science, arts and sports at universities for the exceptionally talented children who can optionally enroll in schools at the age of 3 in the Czech Republic, Luxemburg and Holland. For example, after a 3.5-4 years education at preschool, primary school and secondary school levels, teachers who will work with exceptionally talented children continue their education for 1-1.5 years and graduate with the qualified personnel title in branch and education levels (EC, 2006; EC, 2018a; EC, 2018b; 2018c; Eurydice, 2018, Ministry of National Education MEB, 2012a, 2012b; Council of Higher Education YOK, 2018). While the special education teaching program in the 2018-2019 academic year in Turkey includes performance and integration based courses regardless of the type of need, it is 
seen that there is Learning Disability and Exceptional Talent (4 ECTS) course in the second term as the only course including exceptional talent term. It can be said that the special education teaching students gain knowledge and experience in this field in the $1^{\text {st }}$ and $2^{\text {nd }}$ years in Turkey, as the educational practices for all individuals with special educational needs are mentioned in Integration in Special Education course although exceptional talent term is not included in the content of the course and they make observations in Science and Art Centers in school and institution observations (Ministry of National Education MEB, 2012a, 2012b; Council of Higher Education YOK, 2012a, YOK, 2012b, YOK, 2018a).

The teachers should have implementing skills as well as subject field efficacies and should follow the innovations in science and math, so that the individuals can receive an education as questioning, productive, innovator individuals who can cooperate in accordance with entrepreneurship culture and cooperation and can follow technological and scientific developments in our education system (Ministry of National Education MEB, 2016; Council of Higher Education YOK; 2012a, YOK, 2012b; YOK, 2018). In this sense, a comparison of teacher training programs in an international sense is significant and the teachers should take the individual differences into account and aim to train students as individuals who have high level thinking skills, can develop products, have teamwork skills, are not afraid of making mistakes and have high level of self-confidence instead of giving the theoretical information with direct speech.

As a result, the findings of this comparative study have been thought to contribute to the assessment of special education teaching program, Bologna process studies in teacher training programs and regulations related to the ECTS compatibility of the courses.

\section{References}

ASIS (Anadolu-Sak Intelligence Scale). (2018). ASIS Turkey's first domestic intelligence scale, Anadolu ASIS. Retrieved July 14, 2018, from https://www.projeiq.com

Baykoç Dönmez, N. (2010). Gifted and exceptionally talented children and their education. In N. Baykoç (Ed.), Special education for teaching programs (pp. 301-338). Gündüz Publishing.

CCEA (Council of European). (2006). Gifted and talented children in (and out of) the classroom. Retrieved June 6, 2013, from http://www.sess.ie/sites/all/modules/wysiwyg/tinymce/jscripts/tiny_mce/plugins/filemanager/files/Categorie s/ASD/27CCEA_report_2006.pdf

Davaslıgil, Ü. (2004). Gifted children. In R. Girin, A. Kulaksızoğlu, \& A. Bilgili (Eds.), Gifted children: Selected Articles Book (pp. 211-218). İstanbul: Children Foundation Publishing.

EC (European Commission). (2006). Eurydice Network on Education Systems and Policies in Europe. Retrieved April 26, 2013 from http://eacea.ec.europa.eu/education/eurydice/index en.php

EC (European Commission). (2011). Council conclusions on the role of education and training in the implementation of the 'Europe 2020' strategy. Retrieved February 11, 2013, from http://eurlex.europa.eu/LexUriServ/LexUriServ.do?uri=OJ:C:2011:070:0001:0003:EN:PDF

EC (European Commission). (2018a). Compulsory Education. Retrieved July 13, 2018, from https://eacea.ec.europa.eu/national-policies/eurydice/content/recommended-annual-instruction-time-full-tim e-compulsory-education-europe-\%E2\%80\%93-201718_en

EC (European Commission). (2018b). Information Network on Education in Europe and Network on Education Systems and Policies in Europe (Eurydice Network on Education Systems and Policies in Europe). Retrieved July 13, 2018, from https://eacea.ec.europa.eu/national-policies/eurydice/national-description_en

EC (European Commission). (2018c). Member countries. Retrieved July 13, 2018, from https://europa.eu/european-union/about-eu/countries_en\#the_28_member_countries_of_the_eu

Emir, S. (2017). Program design in the education of exceptionally talented (S. Emir ed.). Pegem Akademi. Ankara.

Enç, M. (2005). Superior intelligence. Ankara: Gündüz Publishing.

EU (European Union). (2017a). Education, training and youth. Retrieved December 25, 2017, from http://europa.eu/european-union/about-eu/countries_en

EU (European Union). (2017b). Topics of the European Union. Retrieved December 25, 2017, from http://europa.eu/european-union/topics_en

European Commission/EACEA/Eurydice. (2018). Recommended Annual Instruction Time in Full-time 
Compulsory Education in Europe - 2017/18. Eurydice - Facts and Figures. Luxembourg: Publications Office of the European Union.

Idin, Ş., \& Kayhan, N. (2016). Special education practices for gifted-talented students in primary school period in European Union Member Countries and Turkey. Ahi Evran Üniversitesi Kırşehir Eğitim Fakültesi Dergisi (KEFAD), 17(2), 17-31.

Kirişçi, N., \& Sak, U. (2018). Characteristics and diagnosis of gifted. In M. Melekoğlu \& U. Sak (Eds.), Learning disability and exceptional talent (2nd ed., pp. 154-170). Pegem Academy.

MEB. (2009). Science and Arts Centers Directive. Retrieved June 8, 2014. from $\mathrm{http}: / /$ mevzuat.meb.gov.tr/ html $/ 25930 . \mathrm{html}$

MEB. (2012a). Special Education Services Regulation Institutions for the Education of Gifted Individuals. Retrieved May 25, 2013, from http://ozegep.meb.gov.tr/index.php/ogretmenler/engelli-haklari

MEB. (2012b). Investigation of international policies and practices in the education of gifted individuals report. $\begin{array}{lcr}\text { Retrieved May } & 25, & 2013, \\ \text { http://orgm.meb.gov.tr/mebiysdosyalar/201302/12114109stnyeteneklerineitimi.pdf }\end{array}$

MEB. (2016). STEM (Science, Technology, Engineering, Math) Education report. Retrieved July 14, 2018, from http://yegitek.meb.gov.tr/STEM_Egitimi_Raporu.pdf

MEB. (2018). Special education services regulation. Retrieved July 8, 2018, from http://www.resmigazete.gov.tr/eskiler/2018/07/20180707-8.htm

Miedel, W. T., \& Reynolds, A. (1999). Parent involvement in early intervention for disadvantaged children: Does it matter? Journal of School Psychology, 37(4), 379-402. https://dx.doi.org/10.1016/S0022-4405(99)00023-0

Mönks, F. J., \& Pflüger, R. (2005). Gifted Education in 21 European Countries: Inventory and Perspective. Retrieved July 13, 2018, from http://ksv-projekty.vsb.cz/icpn/repo/gifted_education_21_eu_countries.pdf

Pretis. M. (2009). Early childhood intervention in Austria: An overview of 30 years of development and future challenges. International Journal of Early Childhood Special Education (INT-JECSE), 1(2), 127-137.

Sak, U., Bal Sezerel, B., Ayas, B., Tokmak, F., Ozdemir, N., Demirel Gürbüz, Ş., \& Opengin, E. (2016). Anadolu Sak Intelligence Scale (ASIS) implementing book. Anadolu Üniversitesi ÜYEP Merkezi. Eskişehir. Retrieved July 14, 2018, from https://www.researchgate.net/publication/311143632_ANADOLU_SAK_ZEKA_OLCEGI_ASIS_GUVENI RLIK_VE_GECERLIK_RAPORU

TUBITAK (Scientific and Technological Research Council of Turkey). (2012). Gifted. Retrieved July 14, 2018, from http://www.tubitak.gov.tr/sites/default/files/10 ek-1ustunyetenekliler.pdf

UNICEF. (2011). Unicef annual report. Retrieved June 6, 2016, from http://www.unicef.org/nutrition/files/UNICEF_Annual_Report_2011_EN_060112.pdf

Yıldırım, A., \& Şimşek, H. (2008). Qualitative research methods in the social sciences (7th ed.). Seçkin Publishing. Ankara.

YOK (Council of Higher Education). (2012a). Council of Higher Education, Universities. Retrieved from http://www.yok.gov.tr/content/view/531

YOK (Council of Higher Education). (2012b). Council of Higher Education, Bologna Process. Retrieved from http://bologna.yok.gov.tr/

YOK (Council of Higher Education). (2018). Special education teaching undergraduate program. Retrieved July 8 , 2018 , from http://www.yok.gov.tr/documents/10279/41805112/Ozel_Egitim_Ogretmenligi_Lisans_Programi.pdf

\section{Copyrights}

Copyright for this article is retained by the author(s), with first publication rights granted to the journal. This is an open-access article distributed under the terms and conditions of the Creative Commons Attribution license (http://creativecommons.org/licenses/by/4.0/). 